\title{
Product-Market Growth Strategies and the Performance of Retail Supermarkets in Nairobi City County, Kenya
}

\author{
Jane N. Wanjohi \\ Jomo Kenyatta University of Agriculture and Technology \\ Department of Entrepreneurship, Technology and Leadership Management \\ janenje@gmail.com \\ Jane W. Gathenya \\ Jomo Kenyatta University Agriculture and Technology \\ Department of Entrepreneurship, Technology and Leadership Management \\ jwgathenya@gmail.com \\ John M. Kihoro \\ Co-Operative University of Kenya \\ Directorate of Computing and E-Learning \\ kihoro.jm@gmail.com
}

\begin{abstract}
The purpose of this study was to establish the influence of Product - Market Growth (PMG) strategies on the performance of retail supermarkets in Nairobi City County. Guided by the philosophy of logical positivism, descriptive design involving quantitative and qualitative approaches was used. The sampling frame for the study was made of 143 out of the possible 227 supermarkets in Nairobi City County (Retail Trade Association of Kenya, 2018). The study found that product-market growth strategy has a significant influence on the performance of retail supermarket in Nairobi City County, Kenya. Product diversification had the highest impact on performance, followed by collaborative networks strategy and finally, market penetration. The study recommends the use of collaborative networks, product diversification, as well as market penetration strategies. It further points out the need to strengthen this study by undertaking a more elastic longitudinal study.
\end{abstract}

Key Terms: Collaborative networks, Firm Performance, Market Penetration, Product Diversification.

\section{Background}

Every firm in an industry develops a strategy either explicitly through a formal planning system or implicitly through the actions of various functional departments (Porter, 1980). Product- market growth strategies are involved with the products and markets a firm may engage in (Johnson, Scholes and Whittington, 2008). These strategies give a firm a unique positioning in the minds of consumers guaranteeing the highest degree of performance through strategic advantage (Armstrong, Kotler and Brennan, 2018). Today's global retailers have become more strategic in their expansion and in avoiding the pitfall of entries into developing markets unlike in the past where they played a riskreward game of either tremendous growth or unexpected disaster (ATKearney, 2014). The increasing middle class has backed the modernization of the retailing sector in a lot of African countries, and these economies are now moving toward consumption-driven markets (Deloitte, 2017).

\subsection{Retail Supermarkets in Kenya}

The Kenyan wholesale and retail trade is one of the fastest expanding sub-sectors, currently accounting for 7.3\% contribution to the Gross Domestic Product (GDP) according to Republic of Kenya (ROK), (2018c). Kenya Institute of Public Policy Research and Analysis (Kippra) (2013) acknowledges that in the last decade, supermarkets have grown at a very high rate and that their development is expected to stimulate expansion in construction and property development especially at the county level. Drivers of rapid growth of supermarkets in Kenya are given by Kippra (2013) as changing consumer lifestyles, increased urbanization, the likelihood of having a female household member in the labor force, and the economic growth experienced through the past decade. 


\subsection{Statement of the Problem}

In spite of the critical role and positive outcomes that product- market growth strategies play on organizational performance (Ansoff, 1957: Wanjiru and Gongera, 2015), retail supermarkets in Kenya have experienced mixed patterns of positive and negative growth (ROK, 2008), leading to lower profits, despite high volumes, and the result has been two thirds of the firms dropping out of the growth curve, hence, their deaths in the volatile competitive retail markets (Ouma, Mwangi and Oduk, 2013). This has turned it to be more difficult for the existing firms to maintain market share and achieve growth (Mumassabba, Muchibi, Mutua and Musiega, 2015) resulting in some of the leading supermarkets going into receivership or/and closure (ROK, 2018; Uchumi Supermarkets, 2016). This is in spite of the need to strengthen the sector, which is essential in the achievement of vision 2030. This begs for an explanation on the role PMG strategies have on the performance of these firms.

\subsection{Objective of the Study}

The motivating objective of this study was to determine the influence of product-market growth strategies, namely, market penetration, product diversification, and collaborative networks on the performance of retail supermarkets in Nairobi City County, Kenya.

\subsection{Significance of the Study}

This study will be of value to policymakers in the government as the retail trade sector is one of the priority sectors expected to spur the Kenyan economy towards the attainment of vision 2030 goals which envisions a formal wholesale and retail trade sector that is efficient, multi-tiered and diversified in both product range and innovativeness (ROK, 2007).

\subsection{Scope of the Study}

The study was limited to a geographical scope of Nairobi City County. Being the capital city of Kenya and with a population of 3,134,261 and 985,016 households accounting for $11.23 \%$ of Kenya's population (ROK, 2018), Nairobi was currently estimated to account for $70 \%$ of the modern grocery market with a $40.2 \%$ share of national retail sales. Nairobi represents the bulk of urban life and is identified as the principal location for investment in modern retailing, and consequently, global retailers with interest in Kenya are likely to focus almost exclusively on this city (Deloitte and Planet Retail, 2012).

\section{Literature Review}

\subsection{Theoretical Framework}

This study was anchored on Ansoff's Product/Market Growth Model, which was formulated by Ansoff (1957). The model offers simple and useful strategies that result in organizational growth. The Ansoff Matrix is a strategic planning setup that links an organization's marketing strategy with its general strategic direction. Ansoff's product/market matrix suggests that a firm's growth depend on whether it markets new or existing products in new or existing markets. The Matrix outlines four possible avenues for growth, namely market penetration, product development, market development, and diversification. Each of these strategic selections holds different opportunities and weaknesses for various organizations, and would, therefore, be used differently in different organizations. Market penetration is concerned with increasing sales of existing products to existing markets. Product development develops new products to sell in existing markets. Market development develops new markets for existing products, while Diversification takes new products into new markets. Diversification strategy improves the growth pattern and the stability of the company. According to Mudambi (1994), Ansoff alleged that the interaction between strategic choices could stimulate even more exceptional results through the creation of synergy. This model, therefore, offers strategic managers a wide range of selection of strategies that enhance their firm's performance and hence instigates the main objective of this study on the influence of product- market growth strategies on the performance of retail supermarkets in Nairobi City County, Kenya. From the theoretical framework, this study conceptualized that market penetration, product diversification, and collaborative networks influenced the firm's performance.

\section{2 Conceptual Framework}

This study hypothesized that product- market growth strategies of market penetration, product diversification, and collaborative networks play a significant role in the firm's performance (Figure 1). 


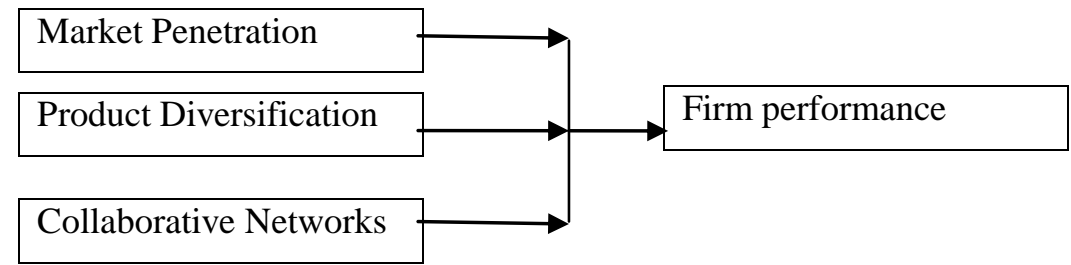

Independent Variables

Dependent Variables

Figure 1: Conceptual Framework

This is in line with Hill, Schilling, and Jones (2016) who suggest that strategic executives must choose strategies that work together to assist their firms in utilizing resources most effectively to achieve high performance. A review of the literature shows Product-Market strategy is explained by Market Penetration, product diversification, and collaborative networks (Ansoff, 1957; Wanjiru \& Gongera, 2015).

\subsection{Empirical Review}

According to Wanjiru et al. (2015), Product-market growth strategies involve a significant increase in performance objectives (usually sales or market share) beyond previous levels of performance. The market penetration, market development, product development, and diversification strategies were found to positively influence the performance of (SMEs) in Thika, Kenya. Market penetration contributed significantly to the performance of SMEs. The study recommends that SMEs should embrace market penetration strategies to spur the growth of their businesses. Similarly, Gecheo, Thuo, and Byaruhanga (2016) found that market penetration strategy influences customer experience management directly whereby an increase in market penetration approach leads to an increase in customer experience management, and consequently, firm performance.

Santarelli and Tran (2015) conducted a joint analysis of diversification decision, degree of diversification, and outcome of diversification with both parametric and semi-parametric approaches to control for sample selection. The census results after analyzing data from Vietnam showed that diversification has a curvilinear influence on profitability. It improves a firms' profit only to a certain extent, after which more diversification results in a decrease in performance. Firms should, therefore, consider only optimal levels of product diversification in pursuit of increasing their product offerings beyond their primary business. Regarding collaborative networks, Basole (2016) studied the topological elements of inter-firm collaboration networks in the global electronics industry. Describing and executing a data-driven evaluation and conceptualization of well-performing firms, the conclusion was that high-performing businesses exhibit noteworthy interactive collaborative networks impact, making critical administrative contributions to the general design, engineering, and administration of collaborative networks. Similarly, an investigation was done by Keung \& Liyin (2017) examining the relationship between contractors' network performance and strong business competitiveness. The network techniques were found to influence contractors' network, while the network outcomes changed competitiveness attributes. The study commended that contractors should progress their firm competitiveness through inter-firm collaboration among project connected members.

\section{Research Methodology}

\subsection{Research Design}

Based on the philosophy of logical positivism, this study adopted a descriptive design that combined both quantitative and qualitative approaches. This design was preferred because the study obtained information using a questionnaire. Quantitative design was achieved through the use of Likert- type questions while the qualitative approach was gained through the use of open-ended questions.

\subsection{Target Population}

The target population of this study was the retail supermarket stores in Nairobi City County. Nairobi represents the bulk of urban life and is identified as the primary location for investment in modern retailing, having a $40.2 \%$ share of national retail sales (Diloitte \& Planet Retail, 2012). The study employed the sample survey method and then generalized from the sample observation to the community from which the sample was selected or drawn.

\subsection{Sampling Technique}

Since the population of 227 supermarkets was heterogeneous in terms of the number of branches each supermarket had, the first stage involved dividing it into sub-populations that were more homogeneous sharing the same characteristics. This yielded three strata with the first one having more than ten branches, the second having 2 to 9 branches and the last one comprising of single establishments. 
This ensured equitable representation of the population giving more precise estimates for each stratum and more accurate forecast for each of the parts in the sample (Kothari, 2004). Proportional allocation was then done in which the sizes of the sample from the different strata were kept proportionate to the size of the study sample. Purposive sampling was used to select supermarkets from where data was collected. Data was collected from the headquarters in the case of stratum 1 and 2 and individual supermarkets in layer three since they were single establishments.

\subsection{Data Collection Instruments and Measurement of Variables}

In this study, a questionnaire was used in collecting data from Chief Executive Officers, supervisors, or managers as applicable. It had a five-point Likert-type scale as well as open-ended questions. The respondents rated each item by stating the level of agreement ranging from strongly disagree to strongly agree for all the variables. Open questions probed further the influence of PMG strategies on the performance of retail supermarkets. The performance of a firm was measured by the degree of satisfaction on the growth levels of sales volume and market share. Due to the sensitivity of obtaining information related to financial performance where owners of a firm were not willing to cooperate or information was not available, a 5 point Likert scale psychometric instrument was used to capture data using indirect financial measures where the degree of satisfaction with firm's performance was used based on owner's perceptions on performance. The scale ranged from $(1=$ Strongly Disagree, $2=$ Disagree $3=$ Not Sure, $4=$ Agree, $5=$ Strongly Agree). The mean score was then calculated as an average of the 5 items examined on the firm's perceived performance. A mean score of 3.4 and above on each item indicated that the respondents agreed with the statement given while those with a mean score below 3.4 suggested disagreement. Then the average mean rating per firm was obtained from aggregating the means on performance and dividing by five items. The higher the score, the better the statement in terms of the firm's perceived performance. This method was used in the measurement of both the independent and dependent variables.

\subsection{Data Processing, Analysis, and Presentation}

Qualitative analysis for the data collected using the open-ended questions was analyzed using thematic content analysis that helped in making inferences. Quantitative data analysis, on the other hand, included both descriptive and inferential statistics which enabled meaningful distribution of scores of measurement using indices and statistics. The main descriptive statistical analysis included mean, percentages, standard deviation, and frequencies to cater for the Likert scales that were used in the study. Inferential statistics were used to analyze the relationship between variables. This was achieved through correlation and regression analysis. Pearson product-moment of correlation was used to determine the influence of PMG strategies on performance of retail supermarkets while linear multiple regression analysis was used to explain the extent to which independent variables explain variation in firm performance (dependent variable).

\subsection{Statistical Measurement Model}

This study adopted the multiple regression model to measure objectives 1-3. The regression analysis helped to compare the influence of each PMG strategy construct on performance. The PMG strategies as independent variables were regressed against the performance of the firm. This provided the magnitude of influence that each construct has on business performance. The proposed regression model of the study is as follows:

$\mathrm{Y}=\beta 0+\beta_{\mathrm{i}} \mathrm{X}_{\mathrm{i}}+\varepsilon,(\mathrm{i}=1,2,3) \quad$ (1a)

$\mathrm{Y}=\beta_{\mathrm{o}}+\beta_{1} \mathrm{X}_{1}+\beta_{2} \mathrm{X}_{2}+\beta_{3} \mathrm{X}_{3}+\varepsilon \quad(1 \mathrm{~b})$

Where:

$\mathrm{Y}$ is the performance of the Retail Supermarkets in NCC, Kenya; $\beta_{\mathrm{o}}=$ Is constant which represents the performance of supermarkets when the independent variables under consideration are zero; $X_{1}=$ The market penetration index; $X_{2}=$ The product diversification index; $X_{3}=$ The collaborative networks index; $\beta_{1}, \beta_{2}$ and $\beta_{3}$ represent the coefficient of $X_{1}$, $\mathrm{X}_{2}$, and $\mathrm{X}_{3}$ respectively; $\varepsilon$ represents the error term.

The coefficient is significant in situations where the significant level is between $\mathrm{P}<0.05$. The hypotheses were tested for the regression model coefficients. That is: $\mathrm{Ho}_{\mathrm{i}}: \beta \mathrm{i} \neq 0(\mathrm{I}=1,2,3)$ versus $\mathrm{H}_{1 \mathrm{i}}: \beta \mathrm{i} \neq 0$. The regression output provides $\mathrm{t}-$ values and corresponding $\mathrm{p}$-values. If $\mathrm{P}$-value $<0.05$, then $\mathrm{Ho}_{\mathrm{i}}$ was rejected, which implies that $\mathrm{X}_{\mathrm{i}}$ has a significant influence on $\mathrm{Y}$. The direction of the influence was indicated by the sign of the coefficient.

\section{Results and Discussion}

Out of the 143 questionnaires administered, 134 were filled and returned. This represented $93 \%$ of responses. The highest percentage of respondents was managers at $48.5 \%$. C.E.Os were $25 \%$ while directors were $20.9 \%$. Supervisors who responded were $2.2 \%$ while $3 \%$ did not indicate the position they held at the firms. The study targeted this high level of management because the chief executive officers, supervisors or managers of the supermarkets are well placed on elucidating on organizational strategies since they are responsible for critical decision making of the firms. 
The study found that $68.6 \%$ of the respondents had served between one and five years in their current positions. 26.9\% had served between six and ten years whereas $1.5 \%$ had served for more than 11 years. It was noted that those who served for more years were fewer than the new entrants. Having a young human resource in management is an indicator that firms experiment on new ideas that would lead to the growth of the firm. The International Labor Organization (ILO), (2011) says that a human resource with high levels of education result in a more skilled and diligent personnel which is capable of being more productive of a higher standard of goods and services, hence speedy growth. The results showed that $3.5 \%$ of the businesses had operated for more than 10 years, $44 \%$ for a period ranging between 6 to 10 years and $47 \%$ had operated for a period of 0 to 5 years. This indicates that the sector is young with many new entrants in the market.

\subsection{Firm Performance}

The dependent variable in this study was the performance of retail supermarkets in Nairobi City County, Kenya. On a five-point Likert scale, respondents were asked to rate the performance of their firms over the last five years. The study findings showed that $88 \%$ of the respondents reported that their firm's sales volume had increased, whereas $89.5 \%$ reported that their market share had increased. Similarly, respondents were asked to indicate the general status of the financial performance of their firm. Overall, 64.9\% reported that their firm's overall performance was very good or excellent, while 30.5 said that their overall performance was fair. Only $2.3 \%$ reported a bad overall performance. A further $2.3 \%$ indicated that their performance improved every year.

\subsection{Descriptive Analysis}

Study respondents were requested to indicate on a five-point Likert scale, their level of agreement on several statements describing their firm's PMG strategies and concerning their performance. Results show that $86.2 \%$ agreed that their firms were very keen on expanding our market using the existing products. This indicates that the firms have embraced the market penetration strategy. $98.8 \%$ stated that they were always keen on the pricing of their products. This means that they had incorporated the penetration pricing strategy, which is essential for firm growth. $40.6 \%$ frequently relied on research and development, indicating that retailers need to enhance their research to increase their market share. 93.2\% considered growing in the retail supermarket industry an indicator that, retailers had not diversified their businesses. $98.5 \%$ indicated that they had continuously added new products for selling in the last five years, which shows a great extent of product diversification. While $71.6 \%$ remained neutral, $13.4 \%$ of the respondents agreed to their firms always sharing knowledge with other retail supermarkets. This is an indicator of the minimal extent of collaborations among the retailers. However, collaborations and partnerships were noticed between the retailers and suppliers as $98.5 \%$ of the firms agreed on always keeping a strong relationship with suppliers. Retailers indicated a wish to make their supplies where possible, as evidenced by $89.6 \%$ of the respondents who agreed that establishing a manufacturing unit (like Deli) which ensured constant supplies.

On ways in which the supermarket achieved market penetration, offering low prices took the lead at $44.1 \%$ and giving discounts closely followed at $37 \%$. The two strategies were, therefore, popular in enhancing market penetration among the retailers. Mentioned also as ways of achieving market penetration are advertisements, keeping the stores open for more extended periods as well as firms being strategically located, among others. Though minimal, respondents also indicated that the supermarkets had diversified their operations. Some of the areas of diversification in which the firms were engaged include hotels at $8.2 \%$, cyber cafes at $6.7 \%$ farming at $1.5 \%$, mobile money at $1.5 \%$ among others. However, $73.1 \%$ were nonresponsive, and this can be an indicator that many firms have not diversified their operations. On collaborative networks, respondents indicated that their firms collaborate with other firms in areas such as purchases and supplies at $58 \%$ transportation at $28.4 \%$, research, among others. Collaboration is, therefore done at a vertical level with suppliers. Generally, majority of the respondents thought that PMG strategy influenced growth in sales, profits, and market share (Mean $=4.01$, Std. Dev $=.452)$.

\subsection{Inferential Statistics Analysis}

The study findings seen in Table 1 showed that there was a significant positive correlation between product-market growth strategies and firm performance $r=0.291$, $p$-value $=0.01$ ). 
Table 1: Correlation Analysis

\begin{tabular}{|l|l|l|l|}
\hline Correlations & & \multicolumn{2}{|l|}{} \\
\hline & Pearson Correlation & 1 & Performance \\
\hline & Sig. (2-tailed) & & \\
\cline { 2 - 4 } & $\mathrm{N}$ & 134 & \\
\hline \multirow{5}{*}{ Performance } & Pearson Correlation & $.291^{* *}$ & 1 \\
\cline { 2 - 4 } & Sig. (2-tailed) & .001 & 133 \\
\hline & $\mathrm{N}$ & 133 & \\
\hline \multirow{2}{*}{$* *$ Correlation is significant at the 0.01 level (2-tailed). } &
\end{tabular}

Regression model results on the relationship between PMG strategy and performance of retail Supermarkets (Table 2) indicate that, of the variations in performance of retail supermarkets in NCC, market penetration $\left(\mathrm{X}_{41}\right)$ explained $12 \%$, product diversification explained $28.6 \%$ while collaborative networks explained $11.2 \%$. The findings are supported by a coefficient of determination $\left(\mathrm{R}^{2}\right)$ of $12.1 \%, 28.6 \%$, and $11 \%$ respectively. Product diversification, therefore, is a more preffered strategy of product-market growth strategy in enhancing firm performance. Further, results indicate that all the models for PMG strategy were positive and statistically significant as supported by a p-value of $0.001\left(\mathrm{X}_{1}\right)$, $<0.001\left(\mathrm{X}_{2}\right)$ and $0.002\left(\mathrm{X}_{3}\right)$ with beta coefficients of $.064, .106$ and .523 respectively. This implies that $\mathrm{X}_{1}, \mathrm{X}_{2}, \mathrm{X}_{3}$ are good predictors of performance. Based on the beta coefficients, the coefficients of the three constructs are ranked as collaborative networks $\left(\beta_{3}=0.523\right)$, product diversification $\left(\beta_{2}=0.106\right)$ and lastly, market penetration $\left(\beta_{1}=0.064\right)$. The results, therefore, imply that $X_{3}$ best explains performance, followed by $X_{2}$ and lastly $X_{1}$.

Table 2: Regression Analysis for Constructs of PMG strategy and Firm Performance

\begin{tabular}{|l|l|l|l|}
\hline & Market Penetration $\left(\mathrm{X}_{1}\right)$ & $\begin{array}{l}\text { Product Diversification } \\
\left(\mathrm{X}_{2}\right)\end{array}$ & $\begin{array}{l}\text { Collaborative } \\
\text { Networks }\left(\mathrm{X}_{3}\right)\end{array}$ \\
\hline Constant & 2.968 & 2.406 & 3.172 \\
\hline $\mathrm{B}_{4}$ & .064 & .106 & .523 \\
\hline $\mathrm{R}^{2}$ & .121 & .286 & .112 \\
\hline F- Statistic & 5.854 & 17.064 & 5.384 \\
\hline P- Value & .001 & .000 & .002 \\
\hline
\end{tabular}

The model fitted was:

Model 1: $Y=\beta_{0}+\beta_{1} X_{1}+e$

$\mathrm{Y}=2.968+0.064 \mathrm{X}_{1}$

Model 2: $Y=\beta_{0}+\beta_{2} X_{2}+e$

$\mathrm{Y}=2.406+0.106 \mathrm{X}_{2}$

Model 3: $Y=\beta_{0}+\beta_{3} X_{3}+e$

$\mathrm{Y}=3.172+0.523 \mathrm{X}_{3}$

Where $\mathrm{Y}=$ Performance; $\mathrm{X}_{1}=$ Market penetration; $\mathrm{X}_{2}=$ Product diversification; $\mathrm{X}_{3=}$ Collaborative networks

On the influence of Product - Market Growth Strategy and Retail Supermarket Performance, the coefficient of determination (R squared) of 0.085 shows that $8.5 \%$ of firm performance can be explained by product-market growth strategy. The adjusted R-square of .078 indicates that PMG strategy in exclusion of the constant variable explained the change in firm performance by $7.8 \%$. The remaining $92.2 \%$ can be explained by other factors excluded from the model. An R of 0.291 shows that there is a positive correlation between firm performance and PMG strategy.

Table 3: Product-Market Growth Strategy and Firm Performance

a)Model Summary

\begin{tabular}{|l|l|l|l|l|l|}
\hline Model & $\mathrm{R}$ & $\mathrm{R}$ sq. & F- change & Adj R Sq & Standard error of estimate \\
\hline 1 & .291 & .085 & 12.146 & .078 & .30652 \\
\hline
\end{tabular}

b) Anova

\begin{tabular}{|l|l|l|l|l|l|}
\hline & Sum of squares & df & Mean square & F & Sig \\
\hline Regression & 1.141 & 1 & 1.141 & 12.146 & .001 \\
\hline Residual & 12.308 & 131 & .094 & & \\
\hline Total & 13.449 & 132 & & & \\
\hline
\end{tabular}


c) Coefficients

\begin{tabular}{|l|l|l|l|l|l|}
\hline & $\mathrm{B}$ & Stand. error & $\mathrm{T}$ & Sig & VIF \\
\hline Constant & 2.712 & .284 & 9.541 & .000 & 1.000 \\
Differentiation & .254 & .073 & 3.485 & .001 & \\
\hline
\end{tabular}

\section{Dependent Variable: Performance}

The standard error of estimate (0.30652) shows the average deviation of the independent variables from the line of best fit. These results are shown in Table 3(a). Table 3(b) displays the F statistics, and the results reveal that PMG strategy is statistically significant in explaining the performance of retail supermarkets in NCC, Kenya. An F statistic of 12.146 and a p-value of .001 shows that the model is significant

The study hypothesized that PMG strategy has no significant effect on the performance of retail supermarkets in NCC, Kenya. The study findings indicate that there is a significant positive association between product-market growth strategy and performance of retail supermarkets $(\beta=0.254$ and $p$ value $=0.001)$. Since the $p$-value was less than 0.05 , as shown in Table 3(c), the study rejects the null hypothesis and therefore accepts the alternative hypothesis. The model fitted was:

$\mathbf{Y}=\boldsymbol{\beta}_{0+} \boldsymbol{\beta}_{1} \mathbf{X}_{1}+\mathbf{e}$

$\mathrm{Y}=\mathbf{2 . 7 1 2}+.254 \mathrm{X}_{4}$

Where, $\mathrm{Y}$, is firm performance, $\mathrm{X}_{1}$, is product-market growth strategy. It can then be concluded that product-market growth strategy influences the performance of retail supermarkets in Nairobi City County, Kenya

\subsection{Discussion of Findings on the Relationship between PMG Strategy and Firm Performance}

These results are consistent with previous studies investigating the influence of PMG strategy on firm performance. Wanjiruet al.(2015) who found that market penetration contributed significantly to the performance of businesses. The study was recommending that companies should embrace market penetration strategies to spur the growth of their performance. The results are also in agreement with Gecheo (2016)who posit that market penetration strategy leads to an increase in consumer experience management, and accordingly, firm performance.

On product diversification, the study is congruent with that done by Santerelli et al. (2015) who recommended the use of optimal levels of product diversification in pursuit of increasing their product offerings beyond their primary business to enhance their performance. Similarly, the study is in tandem with that done by Keung et al. (2017) who posits that inter-firm network techniques influence contractors' network which in turn influence network outcomes of competitiveness attributes and thus overall performance.

\subsection{Summary of the Findings and Conclusions}

A business's endeavor to grow depends on whether it markets new or existing products in new or existing markets. Therefore, the performance of a firm depends on how best its products and markets enlarge. This study found that there was a significant positive relationship between PMG strategy and performance of retail supermarkets. The highestrated construct of PMG strategy was collaborative networks which the study found was majorly achieved through collaborating with suppliers in stock purchases as well as with other firms in the transportation of their products. The final construct of PMG strategy is market penetration which was mainly achieved through expanding the market by using the same product lines by opening identical stores in different locations. The study concludes that the growth of a firm through market penetration, product diversification, and collaborative networks ensures improved performance.

\subsection{Study's Contribution to Theory}

The study supports the Product - Market growth model, which was formulated by Ansoff (1957) and offered useful and straightforward strategies that result in organizational growth through a firm's products and markets. This study sought to investigate the influence of product - market growth strategies of product diversification, market penetration, and collaborative networks and found that they drive a firm's performance.

\subsection{Areas for Further Research}

This study used a time-constrained cross-sectional design. The researcher finds this design to be very restrictive and suggests that a more time elastic longitudinal study can be done to measure the product-market strategies' influence on the performance of retail supermarkets.

\section{References}

Ansoff, I. (1957). Strategies for Diversification. Harvard Business Review. 35 (5), 113-124.

Armstrong, G., Kotler, M. \& Brennan, R. (2018). Marketing: An Introduction. Pearson, U.K. $4^{\text {th }}$ Edition. 
ATKearney (2014). Full Stream Ahead for Global Retailers. The 2014 Global Retail Development Index ${ }^{\mathrm{TM}}$.

Basole, R.C (2016). Topological analysis and visualization of inter-firm collaboration networks in the electronics industry. Decision Support Systems, 83; 22-31 https://doi.org/10.1016/j.dss.2015.12.005. Accessed on $18^{\text {th }}$ September 2019.

Boone, H. N. \& Boone, D. A. (2012). Analyzing Likert Data. Journal of Extension. 50(2). http://www.joe.org/joe/2012april/tt2p.shtmlAccessed on $18^{\text {th }}$ May 2018.

Deloitte and Planet Retail (2012). Hidden Cities: The next generation of Retail Markets. It was accessed on $6^{\text {th }}$ May 2015 at WWW2.deloitte.com.

Deloitte (2017). Global Powers of Retailing 2017. The art and science of customers. Accessed on $4^{\text {th }}$ June 2019 at https://www2.deloitte.com.

Gecheo, P. O., Thuo, J. K. \& Byaruhanga, J. (2016). Market Penetration Strategy and Competitiveness of Mobile Telecommunication Service Providers in Kenya. IJRDO-Journal of Business Management. 2(12), 102120. ISSN: 2455-6661. Accessed on $12^{\text {th }}$ December 2018.

Hill, C.W.L., Schilling, M. A. \& Jones, G.R. (2016). Strategic Management: Theory: An Integrated Approach. $\left(12^{\text {th }}\right.$ Ed.).ISBN: 978-1-305-50233-8.

Hoon,C., Sohl, T. \&Rugman, A. (2015). Regional and product diversification and the performance of retail multi nationals. Journal of International Management,21(3). 220-234. https://doi.org/10.1016/j.intman.2015.04.002 Accessed on $11^{\text {th }}$ November 2018

International Labour Organisation. (2011). A Skilled Workforce for Strong Sustainable Growth: A G20 Training Strategy. Geneva, Switzerland: International Labour Office. ISBN 978-92-124277-2.

Johnson, G., Scholes, K. \& Whittington, R. (2008). Exploring Corporate Strategy ( $8^{\text {th }}$ Ed.). Prentice Hall International (UK) Ltd.

Kenya Institute for Public Policy Research and Analysis (2013). Kenya Economic Survey, 2013. Accessed on $3^{\text {rd }}$ July 2014, WWW.kippra.org.

Keung, C \& Liyin S. (2017). Network strategy for contractors' business competitiveness. Construction Management and Economics, 35: (8-9), 482-497. DOI: 10.1080/01446193.2017.1329539Accessed on $12^{\text {th }}$ May 2019.

Kothari, C.R. (2004) Research Methodology-Methods and techniques $\left(2^{\text {nd }}\right.$ revised Ed). Bangalore: New Age International Publishers Ltd.http://192.168.194.112/handle/1/7047. Accessed on $13^{\text {th }}$ August 2018.

Muange, R. \& Maru, L. C. (2015). Strategic alliances on the performance of retail firms in Nairobi County, Kenya. The TQM Journal, 27 (6), 732-740, https://doi.org/10.1108/TQM-06-2015-0075Accessed on 20th June 2019.

Mudambi, S. M (1994). A Topology of Strategic Choice in Retailing. International Journal of Retail \& Distribution Management,22 (4), 32 -40.http://dx.doi.org/10.1108/09590559410062690. Accessed on $14^{\text {th }}$ February 2019.

Mumassabba. J., Muchibi M. W., Mutua S. M., Musiega, D. (2015). Factors Influencing Competitive Advantage among Supermarkets in Kenya: A Case of Nakumatt Holdings Limited. International Journal of Novel Research in Humanity and Social Sciences, 2, (3), 63-77. ISSN 2394-9694. www.noveltyjournals.com. Accessed on $16^{\text {th }}$ May 2019.

Ouma, D., Mwangi, T. \& Oduk, P. M. (2013). Modeling Agility in Kenyan Supermarket Chain Expansion. International Journal of Business and commerce, 2 (8), 21-36.ISSN: 2225-2436

Porter, M. (1980). Competitive Strategy: Techniques for Analyzing Industries and Competitors. New York: Free Press.

Republic of Kenya. (2007). Kenya Vision 2030: A Globally Competitive and Prosperous Kenya. Nairobi: Government of Kenya.

Republic of Kenya. (2008). First Medium Term Plan, 2008-2012. Nairobi: Government of Kenya.

Republic of Kenya. (2018a). Economic Survey. Nairobi. Kenya National Bureau of Statistics.

Republic of Kenya. (2018b). Statistical Abstract, 2018. Nairobi: Kenya National Bureau of Statistics.

Republic of Kenya (2018c). Third Medium Term Plan 2018-2022. Transforming Lives: Advancing Social Economic Development Through the 'Big Four' Government of Kenya.

Santarelli, E\& Tran, H. (2015).Diversification strategies and firm performance in Vietnam: Evidence from parametric and semi-parametric approaches ${ }^{\dagger} .24(1) .31-68$. https: $^{\prime} /$ doi.org/10.1111/ecot.12082.Accessedon29 ${ }^{\text {th }}$ July 2018

Uchumi Supermarkets Limited. (2016). Annual Report and Financial Statements forthe year ended 30 June 2016

Wanjiru and Gonjera (2015). Analysis of Organic Growth Strategies on Performance of small and medium-sized Enterprises: Case of Thika Sub- County, Kenya. European Journal of Business and Management. 7, (5), 180-205.www.iiste.org ISSN 2222-1905 (Paper) ISSN 2222 -2839. Accessed on $17^{\text {th }}$ May 2019. 